\title{
Diet and nematode infection in Proceratoprhys boiei (Anura: Cycloramphidae) from two Atlantic rainforest remnants in Southeastern Brazil
}

\author{
THAÍS KLAION ${ }^{1}$, MAURICIO ALMEIDA-GOMES ${ }^{1}$, LUIZ E.R. TAVARES ${ }^{2}$, \\ CARLOS F.D. ROCHA ${ }^{1}$ and MONIQUE VAN SLUYS ${ }^{1}$ \\ ${ }^{1}$ Departamento de Ecologia, Instituto de Biologia Roberto Alcantara Gomes, Universidade do Estado do Rio de Janeiro, \\ Rua São Francisco Xavier, 524, Maracanã, 20550-013 Rio de Janeiro, RJ, Brasil \\ ${ }^{2}$ Laboratório de Ictioparasitologia, Departamento de Parasitologia Animal, Instituto de Veterinária, \\ Universidade Federal Rural do Rio de Janeiro, BR 465, Km 7, 23890-000 Seropédica, RJ, Brasil \\ Present address: Laboratório de Parasitologia Veterinária, Centro de Ciências Biológicas e da Saúde, \\ Universidade Federal de Mato Grosso do Sul, Avenida Costa e Silva, s/n, \\ Cidade Universitária, 79070-900 Campo Grande, MS, Brasil \\ Manuscript received on September 29, 2010; accepted for publication on March 30, 2011
}

\begin{abstract}
Proceratophrys boiei is an endemic cycloramphid anuran inhabiting the leaf litter of Atlantic rainforests in Southeastern Brazil. We analyzed the whole digestive tract of 38 individuals of Proceratophrys boiei collected in two Atlantic Rainforest areas in the state of Rio de Janeiro, Brazil, to study the diet composition and the helminth fauna associated with this species. The main food items in $P$. boiei's diet were Coleoptera, Orthoptera and Blattaria. Five nematode species were found: Aplectana delirae, Cosmocerca parva, Oxyascaris oxyascaris, Physaloptera sp. (larval stage only) and an unidentified nematode. Overall prevalence was $71 \%$ and mean infection intensity was $7.3 \pm 5.8$ nematodes per individual.
\end{abstract}

Key words: Anura, Proceratoprhys, diet, endoparasitism, neotropics.

\section{INTRODUCTION}

The neotropical genus Proceratophrys (Anura: Cycloramphidae) is distributed mainly in Brazil, with a few species also occurring in Paraguay and northern Argentina (Amaro et al. 2009). These frogs occur through a wide variety of biomes: from the Atlantic Rainforest domain (Izecksohn and Peixoto 1981, Kwet and Faivovich 2001, Prado and Pombal Jr 2008) to the Brazilian Cerrado (Eterovick and Sazima 1998, Amaro et al. 2009, Moreira et al. 2009), the semi-arid Caatinga (Rodrigues 2003), with one species reaching the Amazon rainforest (Giaretta et al. 2000). Proceratophrys species are important components of leaf litter communities in Neotropical forests (Rocha et al. 2001, Boquimpani-

Correspondence to: Thaís Klaion Ferreira

E-mail: thaiskferreira@gmail.com
Freitas et al. 2002) and, because they are relatively large anurans, they can potentially feed upon a large spectrum of prey types and sizes. Studies on diet composition of Proceratophrys species (Giaretta et al. 1998, Boquimpani-Freitas et al. 2002, Teixeira and Coutinho 2002) report the consumption of arthropods, although small vertebrates (frogs) have also been found in some specimens (Boquimpani-Freitas et al. 2002), which may indicate their importance in regulating some species from the arthropod communities, as well as populations of small vertebrates of the leaf litter of tropical forests. Information on the endoparasitic fauna is restricted to only one species, P. tupinamba (= P. appendiculata; see Prado and Pombal Jr 2008), for which five nematodes and one cestode species were reported (BoquimpaniFreitas et al. 2001). 
Proceratophrys boiei (Fig. 1) is endemic to the Brazilian Atlantic Forest domain (though also occurring in areas of transition with Cerrado) (Prado and Pombal Jr 2008), has horn-like appendages above the eyes and a cryptic morphology and coloration (Haddad and Sazima 1992, Costa et al. 2009). The Atlantic Forest supports high rates of anuran biodiversity and equally high threats of disappearance of species (Duellman 1999, Rocha et al. 2001, Young et al. 2004). Recent estimates of existing Atlantic Forest cover report about $11.7 \%$ of its original area, and most of it remains as small, relatively isolated fragments (Ribeiro et al. 2009). The Estação Ecológica Estadual do Paraíso (EEEP) and the Reserva Ecológica de Guapiaçu (REGUA) are two protected forest areas in the state of Rio de Janeiro where $P$. boiei occurs. In this study we evaluate to what extent diet composition and ecological parameters of its endoparasite fauna vary among these populations. Furthermore we present the first report on its endoparasitic fauna.

\section{MATERIALS AND METHODS}

We conducted field samplings in two Atlantic rainforest areas in the state of Rio de Janeiro, Southeastern Brazil. Both constitute Conservation Units: the Estação Ecológica Estadual do Paraíso (EEEP, $22^{\circ} 29^{\prime} \mathrm{S}, 42^{\circ} 55^{\prime} \mathrm{W}$; 40 290 meters high) and the Reserva Ecológica de Guapiaçu (REGUA, $22^{\circ} 24^{\prime} \mathrm{S}, 42^{\circ} 44^{\prime} \mathrm{W} ; 40-400 \mathrm{~m}$ high). These forested areas are about $9 \mathrm{~km}$ far from each other, and both belong to a larger patch of continuous forests covering about 60,000 ha in the central portion of the state. The vegetation of the study areas is predominantly of low montane and sub-montane tropical forest. The climate in the region is wet and warm, with annual rainfall varying from 2000 to $2500 \mathrm{~mm}$, and mean annual temperature is $24^{\circ} \mathrm{C}$ (Rocha et al. 2007, Attias et al. 2009).

We collected 15 individuals of $P$. boiei in September 2004 at EEEP and 23 individuals in October 2004 at REGUA. Frogs were collected by hand or in pitfall traps with drift fences.

Frogs were killed in 50\% ethanol, fixed in $10 \%$ formalin and preserved in $70 \%$ ethanol. In the laboratory we weighted frogs with a digital balance (to the nearest $0.001 \mathrm{~g}$ ) and measured their snout-vent lengh (SVL $\pm \mathrm{SD})$ and jaw width (JW $\pm \mathrm{SD}$ ) with calipers (to the nearest $0.1 \mathrm{~mm}$ ). Frogs were deposited in the Museu Nacional herpetological collection (MNRJ 68764-83, MNRJ 68795-809, MNRJ 68810-11 and in the UNIRIO herpetological collection (Uni-Rio 4297).

We removed the stomachs and examined their contents under stereomicroscope. Each food item was measured in its length and width (with calipers, to the nearest $0.1 \mathrm{~mm}$ ), quantified and identified to the taxonomic level of Order, which was used to group them into categories. The volume of the preys (in $\mathrm{mm}^{3}$ ) was estimated through the ellipsoid formula (Dunham 1983):

$$
V=4 / 3 \pi \cdot(L / 2) \cdot(W / 2)^{2},
$$

where $L=$ length and $W=$ width.

We calculated prey consumption rates separately for each area. The frequency of occurrence (percentage of stomachs containing a given prey type) and percentage of the total number of items are given for each prey category. An index of relative importance $\left(\mathrm{I}_{\mathrm{x}}\right)$ was calculated for each prey category as the sum of their numeric and volumetric proportions and frequency of occurrence divided by three (Howard et al. 1999).

We tested for the relationship between jaw width JW and prey size (length of the largest intact prey found in the stomach) and number of prey per stomach using simple linear regression (Zar 1999). Because samples for each locality were too small, we performed this analysis for both sites pooled together.

Similarly, we considered the parasitism rates for each frog population separately. All worms found along the digestive tract (stomach, small and large intestines) and body cavities were fixed in ethanol $70 \mathrm{GL}$, cleared in solution of lactophenol and mounted on slides for identification under optical microscope. Helminths are currently deposited in a private collection at Departamento de Parasitologia Animal, Universidade Federal Rural do Rio de Janeiro.

Ecological parameters of parasitism such as prevalence (percentage of infected individuals) and mean intensity of infection (average number of parasites per host among infected individuals - expressed as arithmetic mean \pm standard deviation) are given (sensu Bush et al. 1997). The relationship between frog body size and intensity of infection was tested using a randomization test because the data were not normally distributed 


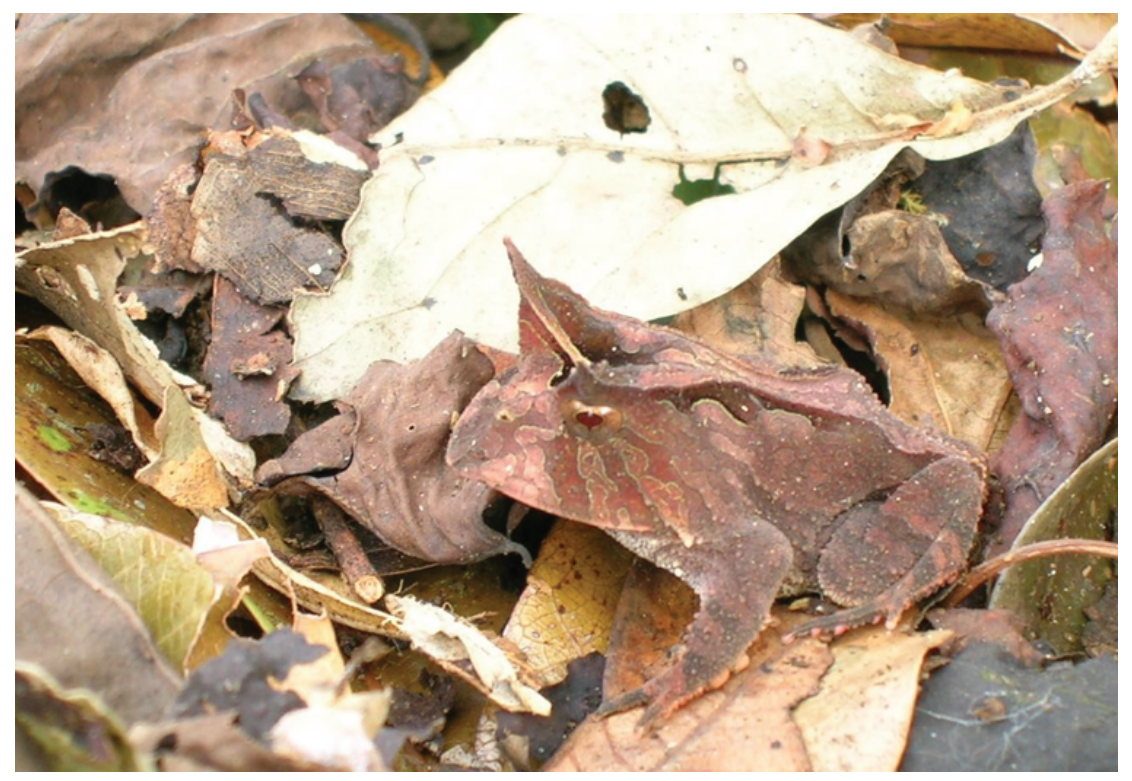

Fig. 1 - Proceratophrys boiei, Estação Ecológica Estadual do Paraíso, Rio de Janeiro, Brasil. Foto: Klaion, T.

and were not homocedastic (Zar 1999). Once again, we pooled data from both localities.

\section{RESULTS}

Five of the 38 individuals captured $\left(\mathrm{N}_{\mathrm{EEEP}}=15\right.$, $\mathrm{N}_{\text {REGUA }}=23$ ) were undoubtedly adults (SVL $>50 \mathrm{~mm}$, see Giaretta et al. 1998). The remaining 33 were presumably juveniles, and we could not determine their sex. There was no significant difference in biometric measures between the two sites, therefore we give such results jointly. Body size (SVL) of the adults ranged from 51.5 to $64.0 \mathrm{~mm}$ (mean $=56.6 \pm 4.7 \mathrm{~mm})$. Among the juveniles, SVL ranged from 21.2 to $48.2 \mathrm{~mm}$ (mean $=33.9 \pm 8.3 \mathrm{~mm}$ ). Body mass (preserved) ranged from 17.7 to $35.7 \mathrm{~g}$ (mean $=23.0 \pm 7.4 \mathrm{~g}$ ) among the adults, and from 0.7 to $17.6 \mathrm{~g}$ (mean $=5.5 \pm 4.6 \mathrm{~g}$ ) among juveniles. Seven of the 38 frogs analyzed had empty stomachs.

Fifty-four food items were recovered and categorized based on their taxonomical classification (level of order) (Table I). The diet of P. boiei was basically composed of arthropods, with some difference between the two sites. Five different arthropod orders were consumed at EEEP, and nine at REGUA. Only three of them coincided in both sites. At EEEP, the most important food category in terms of number $(\mathrm{N}=6)$, frequency of occurrence $(26.7 \%)$ and volume $(82.3 \%)$ was
Blattaria, thus yielding a large value of Index of Importance $(I x=49.3 \%)$ (Table I). Coleoptera was the second most important food item at that site, with an Ix of $17.8 \%$. On the other hand, at REGUA, Coleoptera was the most frequently consumed prey category, being found in $39.1 \%$ of the stomachs. Numerically, Coleoptera was again the most important item $(\mathrm{N}=$ 14), and in terms of volume it represented $48.6 \%$ of all the food found in stomachs of $P$. boiei collected at REGUA. Therefore, it also showed the highest $I x$ (41.3\%). Orthoptera was the second most important food category at REGUA $(I x=20.7 \%)$. Plant material was found in two individuals (one at each site) and consisted of leaf remains (Table I). An average of $2.24 \pm$ 1.48 preys were found per stomach (range: 1-6; both sites pooled).

Prey size was significantly related to jaw width $\left(\mathrm{R}^{2}\right.$ $=0.26 ; F_{1,21}=7.3 ; P=0.013 ;$ Fig. 2). However, jaw width did not explain significantly the number of prey per frog stomach $(\mathrm{P}=0.98)$.

A total of 197 nematodes were found in the digestive tract and (in one case) in the lungs of the frogs. Five nematode species were observed: Aplectana delirae (Fábio 1971), Cosmocerca parva Travassos, 1925, Oxyascaris oxyascaris Travassos, 1920, an unidentified Physaloptera sp. (found only as larvae), and one unidentified nematode found in a single specimen (Table II). 


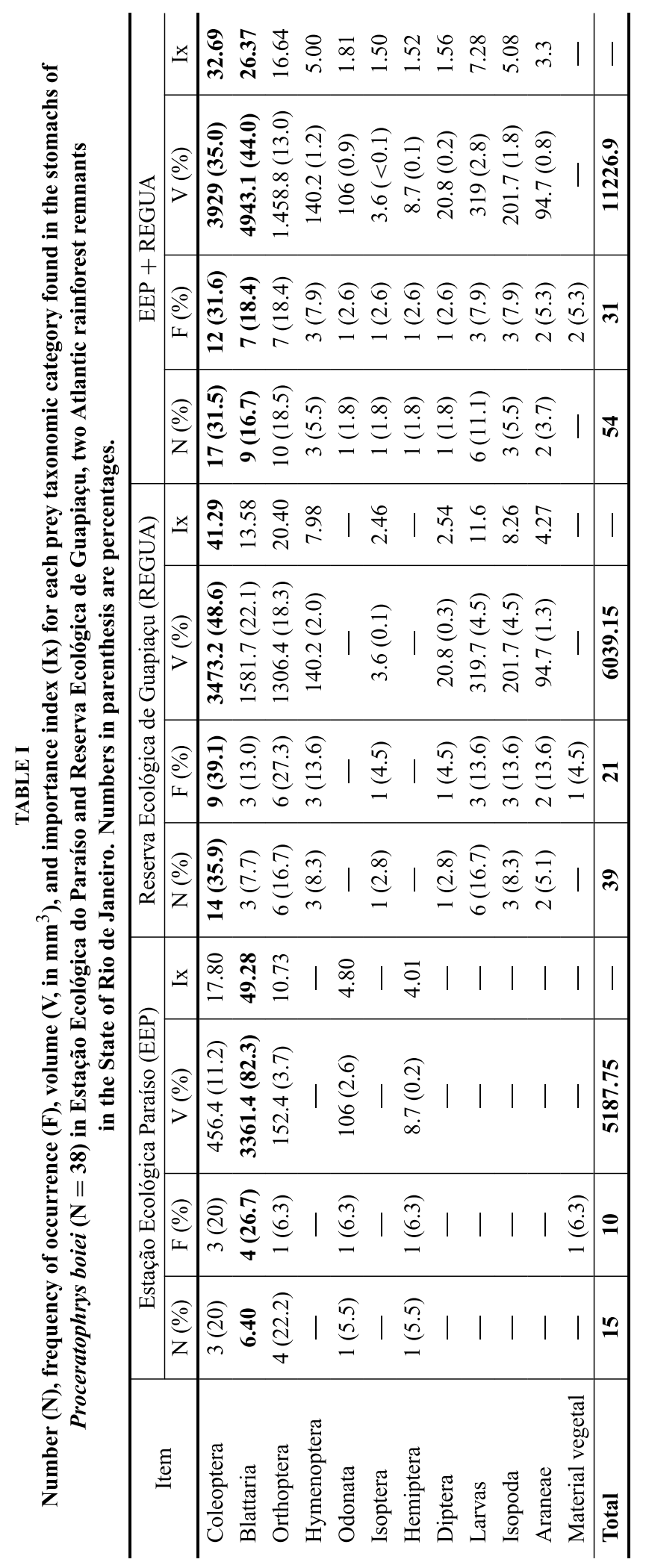




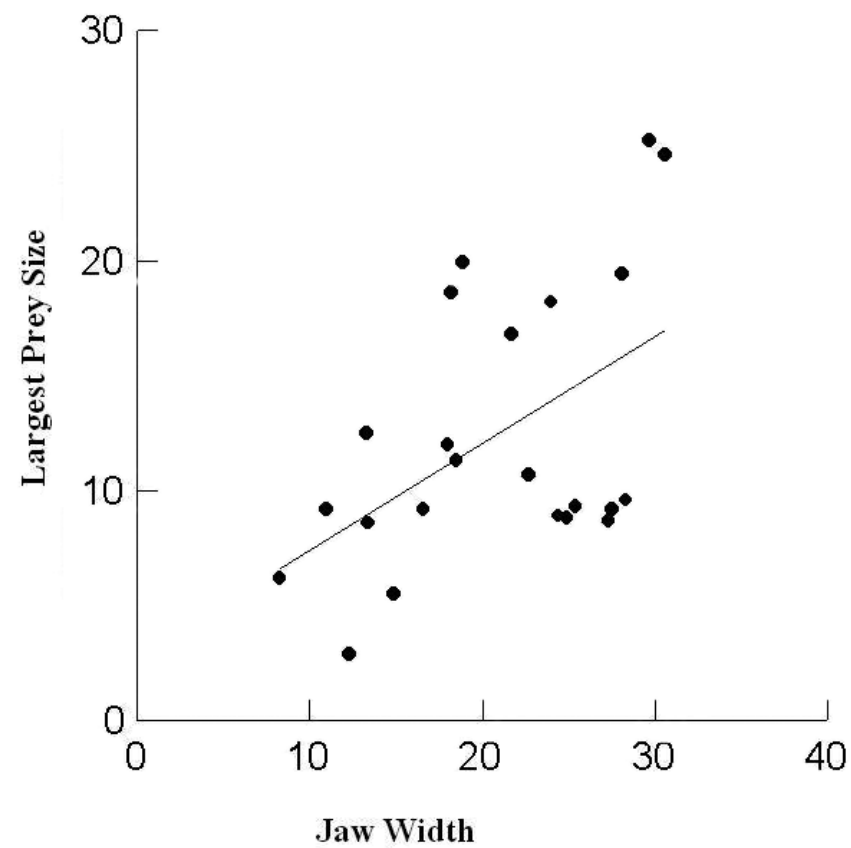

Fig. 2 - Relationship between jaw width $(\mathrm{mm})$ and length $(\mathrm{mm})$ of the biggest prey found in the stomach of Proceratophrys boiei in two Atlantic rainforest remnants in the State of Rio de Janeiro $\left(\mathrm{R}^{2}=0.26 ; \mathrm{F}_{1,21}=7.3 ; \mathrm{P}=0.013\right)$.

TABLE II

Prevalence (in percentage and absolute values), mean intensity of infection ( \pm SD, with range in parenthesis) and number (quantity) of nematodes found in Proceratophrys boiei $(\mathrm{N}=38$ ) in EEEP and REGUA, two Atlantic rainforest remnants in the State of Rio de Janeiro.

( $a=$ found in the stomachs, $b=$ found in the intestines and $c=$ found in the lungs).

\begin{tabular}{l|c|c|c|c|c|c}
\hline \multicolumn{1}{c|}{ Studied area } & \multicolumn{2}{|c|}{ Estação Ecológica Paraíso (EEP) } & \multicolumn{3}{c}{ Reserva Ecológica de Guapiaçu (REGUA) } \\
\hline \multicolumn{1}{c|}{ Nematode species } & $\begin{array}{c}\text { Prevalence \% } \\
(\mathrm{n})\end{array}$ & $\begin{array}{c}\text { Mean intensity } \\
\text { (range) }\end{array}$ & Number & $\begin{array}{c}\text { Prevalence \% } \\
(\mathrm{n})\end{array}$ & $\begin{array}{c}\text { Mean intensity } \\
\text { (range) }\end{array}$ & Number \\
\hline Aplectana delirae & $6.7(1)$ & 2 & 2 & $39.1(9 / 23)$ & $3.6(2.3 ; 1-7)$ & 32 \\
Cosmocerca parva & $53.3(8)$ & $7.5 \pm 5.0(2-17)$ & 60 & $43.5(10 / 23)$ & $7.2(5.3 ; 1-17)$ & 72 \\
Oxyascaris oxyascaris & - & - & - & $8.7(2 / 23)$ & $2.5(2.1 ; 1-4)$ & 5 \\
Physaloptera sp. & $13.3(2)$ & $5.5 \pm 6.4(1-10)$ & 11 & $4.3(1 / 23)$ & 12 & 12 \\
Unidentified species & - & - & - & $4.3(1 / 23)$ & 3 & 3 \\
\hline Total & $60(9 / 15)$ & $8.1 \pm 7.3(1-21)$ & 73 & $78.3(18 / 23)$ & $6.7(5.1 ; 1-17)$ & 124 \\
\hline
\end{tabular}

At EEEP, the overall prevalence was $60 \%$. Seven out of the nine infected frogs hosts were parasitized by a single nematode species. Mean intensity of infection was $8.1 \pm 7.3$, ranging from 1 to 21 . O. oxyascaris and the unidentified species were not found in this study site. Mean number of nematode species per host was $1.22 \pm 0.44$ (range 1-2).

At REGUA, $78.3 \%$ of the P. boiei examined were parasitized, and the mean intensity of infection was $6.7 \pm 5.1$, ranging from 1 to 17 . Once again, few frogs had more than one nematode species in their digestive tract (4 out of 18). Mean number of nematode species per host was $1.28 \pm 0.57$ (range 1-3).

There was no relationship between frog body size and intensity of infection $\left(\mathrm{F}_{1,25}=0.610 ; \mathrm{P}=0.440\right.$; data from both areas pooled). 


\section{DISCUSSION}

In both Estação Ecológica Estadual do Paraíso and Reserva Ecológica de Guapiaçu, Coleoptera, Blattaria and Orthoptera were the most constant and important prey items consumed by the Proceratophrys boiei analyzed. These arthropods usually present large body size and mass, and presumably are important to provide an appropriated amount of food and energy for a frog as $P$. boiei, which is one of the largest frog species in the leaf litter of the Atlantic rainforest. This idea has been previously suggested by Boquimpani-Freitas et al. (2002) for P. tupinamba at Ilha Grande. In fact, the main prey items of Proceratophrys frogs in other Atlantic rainforest areas are arthropods having large size and mass (see Giaretta et al. 1998 for P. boiei; BoquimpaniFreitas et al. 2002 for P. tupinamba; Teixeira and Coutinho 2002 for $P$. paviotti), which reinforces this idea. We found a slight difference in diet composition between the two sites studied. While at EEEP P. boiei fed predominantly on Blattaria, and then Coleoptera, at REGUA it fed predominantly on Coleoptera, followed by Orthoptera. Moreover, a richer spectrum of prey was found in REGUA (nine arthropod orders) when compared to EEEP (five orders), and Blattaria, Coleoptera and Orthoptera were the only orders found as prey items at both sites. Further studies would be necessary in order to determine whether this is a consequence of differences in local availability of food or if there is some sort of selection happening.

Proceratophrys frogs are carnivorous, primarily arthropod consumers. However, some variation in the relative importance of each arthropod group exists. The diet of $P$. tupinamba studied by Boquimpani-Freitas et al. (2002) was largely dominated by orthopterans, whereas P. paviotti ( $=$ P. boiei; Prado and Pombal $\mathrm{Jr}$ 2008) studied by Teixeira and Coutinho (2002) showed a more diversified diet, mainly composed of blattaria, aranae and lepidopteran larvae. Specifically for P. boiei, in two previous studies of diet composition, Coleoptera and Orthoptera were the dominant items in terms of number, frequency and volume over other arthropod groups (Moreira and Barreto 1996, Giaretta et al. 1998). These variations may result from differences in the composition of the arthropod fauna available at the leaf litter of each studied site.
Despite slight differences, as expected, Coleoptera, Blattaria and Orthoptera were together the three most important orders in P. boiei diet in both EEEP an REGUA, jointly accounting for an Index of Importance of over 75.

Proceratophrys boiei is a relatively large-bodied, sit-and wait forager (Giaretta et al. 1998). Thus, it might be advantageous for the species to prey upon large mobile preys (Boquimpani-Freitas et al. 2002) such as beetles, cockroaches and grasshoppers, as we found in this study. Giaretta et al. (1998) studied P. boiei in another Atlantic forest area and found frog remains (Ischnocnema parva) in the stomachs of two of the 38 individuals analyzed. Boquimpani-Freitas et al. (2002) also reported remains of an undetermined eleuthrodactyline frog in the stomach of a specimen of P. tupinamba. These records suggest that Proceratophrys species may be relatively common predators of small anurans inhabiting the leaf litter in the forest floor. Our sample was small and largely composed of juveniles, which probably may help to explain the absence of anurans in the stomachs that we analyzed.

Deliberate consumption of plant material is a relatively rare event for anurans, although it has been observed for some species (Silva et al. 1989, Das 1996). None of the studies that analyzed food habits of Proceratophrys frogs (P. tupinamba, Boquimpani-Freitas et al. 2002; P. paviotii, Teixeira and Coutinho 2002; P. boiei, Giaretta et al. 1998) reported the consumption of plants. In our study, only two of the 38 P. boiei analyzed had ingested plant material. Probably, these plant remains were accidentally ingested during prey capture attempts.

The relationship between frog jaw width and prey size reflects the fact that anurans are gape-limited because they are usually not able to tear or chew their food (Lima and Moreira 1993). It also indicates that there might be an ontogenetic shift in the diet composition of $P$. boiei, as the mean size of individuals differs among the arthropodan orders (Lima and Moreira 1993). We found a significant relationship between jaw width and prey size in the two populations studied. This result was similar to the one found by Boquimpani-Freitas et al. (2002) for P. tupinamba. Using different parameters and analysis - relationship between frog size and the log-transformed volumes of the largest and smallest 
prey plus the relationship between the most important component in a previous PCA analysis (on the variations in proportions of each prey category) and frog size, Giaretta et al. (1998) also found similar results for P. boiei. However, for P. paviotti (Teixeira and Coutinho 2002), no such relationship was found.

Nematode species of the genus Aplectana Railliet \& Henry, 1916 are intestinal parasites of reptiles and amphibians (Travassos 1931, Yorke and Maplestone 1926, Baker 1980). Species from the genus Aplectana are monoxenous, and infection pathway is through the ingestion of infecting larvae (Anderson 2000). Aplectana delirae was originally described parasitizing $R h i$ nella ornata (= Bufo crucifer, see Baldissera et al. 2004) and was later registered in Crossodactylus gaudichaudii (Fábio 1971, Vicente et al. 1990). It has also been reported in P. tupinamba (Boquimpani-Freitas et al. 2001), where it was considered core species. All these accounts come from areas within the Atlantic rainforest Biome in Rio de Janeiro State.

Cosmocerca parva was first described in Hylodes nasus from Angra dos Reis, in Rio de Janeiro State, and later reported parasitizing Leptodactylus marmoratus, $L$. latrans, L. fuscus, L. mystaceus and Physalaemus soaresi in Brazil, Rhinella schneideri, Scinax fuscovarius, Leptodactylus chaquensis and L. elenae in Paraguay, and Rhinella granulosa in Argentina (Fábio 1981, Baker and Vaucher 1984, Mordeglia and Digiani 1998). Species of Cosmocerca are monoxenous, and infection occurs through active skin penetration (and also, occasionally, by ingestion) by infecting larvae (Anderson 2000). Cosmocerca parva was found in the lungs of one of the frogs at REGUA, though in most cases they were found in the intestines. Although C. parva is usually found in the intestines of their hosts, the congeneric C. podicipinus has been described parasitizing the lungs of an anuran host (Pseudopaludicola falcipes) (Gonzalez and Hamann 2004). In fact, some species of this genus (e.g. C. variabilis) need to undergo through a period of development in their host's lungs before establishing themselves in their intestines (Anderson 2000). We found $C$. parva occurring with relatively high prevalence in $P$. boiei at both REGUA and EEEP, acquiring core status (Aho 1990) in the later area. BoquimpaniFreitas et al. 2001 also found one Cosmocerca species
(C. brasiliense) in P. tupinamba from Ilha Grande, also in Rio de Janeiro State.

Oxyascaris oxyascaris was described for the first time in reptiles (Travassos 1920), and then a new species, $O$. necopinus (sinonym of O. oxyascaris - Baker and Vaucher 1985, Bursey and Goldberg 2007), was proposed by Freitas (1958) for specimens found in the small intestine of the frogs Leptodactylus ocellatus, $L$. sibilatrix and Pleuroderma diplolistris. This species was found with low prevalence at REGUA and was not recorded at EEEP.

Physaloptera species have been reported in all classes of terrestrial vertebrates, including several anuran species (Vicente et al. 1990). Boquimpani-Freitas et al. (2001) suggested that, since only larval specimens of Physaloptera are found in amphibians, these nematodes might not be able to complete their cycles in such hosts that probably act as intermediate/paratenic hosts of these parasites. Our results support the contention of Boquimpani-Freitas et al. 2001 because we also found only larvae of Physaloptera infecting $P$. boiei. However, according to Anderson (2000), the development of larvae through subsequent stages depends on the presence of a high quantity of food in the stomach of their host. The acquisition of Physaloptera parasites by the hosts occurs through the ingestion of infected insects, mainly Orthoptera.

The overall helminth prevalence for both $P$. boiei populations studied was relatively high. Cosmocerca parva was the only species that reached core status in one of our localities. Aho (1990) presented mean values of nematode richness (3.54) and mean number of species per hosts $(0.98)$ in a study that covered 83 amphibian populations, mostly from North America. In this study, nematode fauna richness at REGUA (5) and the mean number of species per host in both sites were above the values found by Aho, but still within the ranges (0-9 and 0-2.08, respectively) reported by that author.

We conclude that Proceratophrys boiei is carnivorous, basically consuming arthropods. Coleoptera, Orthopteran and Blattaria are its main prey. Five species of nematodes were found parasitizing P. boiei in the studied areas. These are well known widely distributed amphibian nematodes previously reported in many species of anurans. This is the first report of nematodes for 
P. boiei, which represents a new host record for Aplectana delirae, Cosmocerca parva, Oxyascaris oxyascaris and the genus Physaloptera.

\section{ACKNOWLEDGMENTS}

We thank Nicholas J. Locke - Reserva Ecológica de Guapiaçu (REGUA), and Alcides Picinati - Estação Ecológica Estadual do Paraíso (EEEP) for logistical support and for their permits to work in the areas. We also thank many colleagues for field assistantship in different moments along the study. Davor Vrcibradic kindly read the manuscript offering helpful suggestions. This study (IEF license 006/2005) is part of the results of the "The biodiversity of vertebrates of the Serra do Mar Corridor in Rio de Janeiro State" of the Departamento de Ecologia, Instituto de Biologia, Universidade do Estado do Rio de Janeiro and Instituto Biomas. The Critical Ecosystem Partnership Fund (CEPF) and the Center for Biodiversity Conservation (CCB) of the Conservation International and the Conselho Nacional de Desenvolvimento Científico e Tecnológico - CNPq provided financial support. During the development of this study, research grants of the Conselho Nacional de Desenvolvimento Científico e Tecnológico - CNPq were received by C.F.D. Rocha (Processes No. 307653/2003-0 and 4766842008-0) and M. Van Sluys (Process No. 307773/ 2008-6). CFDR was also granted by the Fundação Carlos Chagas Filho de Amparo à Pesquisa do Estado do Rio de Janeiro (FAPERJ) through the "Programa Cientistas do Nosso Estado" (Process E-26/102.404.2009). M.A. Gomes received a graduate fellowship from Coordenação de Aperfeiçoamento de Pessoal de Nível Superior (CAPES).

\section{RESUMO}

Proceratophrys boiei é um anuro da familia Cycloramphidae que vive no folhico e é endêmico de areas de floresta na Mata Atlantica do Sudeste do Brasil. Nós analisamos o trato digestivo de 38 indivíduos de Proceratophrys boiei provenientes de duas áreas de Mata Atlântica no Estado do Rio de Janeiro, Brasil, para estudar a composição da dieta e a fauna helmíntica associada a esta espécie. Os principais itens alimentares na dieta de $P$. boiei foram Coleoptera, Orthoptera e Blattaria. Cinco espécies de nematóides foram encontradas: Aplectana delirae, Cosmocerca parva, Oxyascaris oxyascaris, Physa- loptera sp. (apenas larvas) e uma espécie de nematóide não identificada. A prevalência total foi de $71 \%$ e a intensidade media de infecção foi de 7,3 $\pm 5,8$ nematóides por indivíduo.

Palavras-chave: Anura, Proceratophrys, dieta, endoparasitismo, neotrópico.

\section{REFERENCES}

Aно JM. 1990. Helminth communities of amphibians and reptiles: comparative approaches to understanding patterns and processes. In: EsCH GW ET AL. (Eds), Parasite communities: Patterns and Processes. New York: Chapman and Hall, p. 157-195.

Amaro RC, PaVAn D And Rodrigues MT. 2009. On the generic identity of Odontophrynus moratoi Jim \& Caramaschi, 1980 (Anura, Cycloramphidae). Zootaxa 2071: $61-68$.

ANDERSON RC. 2000. Nematode parasites of vertebrates, their development and transmission, CABI Publishing, $2^{\text {nd }}$ ed., Wallingford, Oxon, UK, $650 \mathrm{p}$.

Attias N, Raíces DSL, Pessoa Fl, Albuquerque H, Jordẽo-NogueIrA T, MODESTO TC AND BERGALlO HG. 2009. Potential distribution and new records of Trinomys species (Rodentia: Echimyidae) in the state of Rio de Janeiro. Zoologia 26: 305-315.

BAKER M. 1980. Revision of Old World species of the genus Aplectana Railliet and Henry, 1916 (Nematoda, Cosmocercidae). B Mus Natl Hist Nat Paris 4: 955-998.

BAKER MR AND VAUChER C. 1984. Parasitic helminths from Paraguay. VI. Cosmocerca Diesing, 1861 (Nematoda: Cosmocercoidea) from frogs. Rev Suisse de Zool 91: 925-934.

BAKer MR AND VAUCher C. 1985. Parasitic helminths from Paraguay. VII. Systematic position of Oxyascaris Travassos, 1920 (Nematoda: Cosmocercoidea). Rev Suisse de Zool 92: 303-310.

Baldissera FA, CARAmashi U AND Haddad CFB. 2004. Review of the Bufo crucifer species group, with descriptions of two new related species (Amphibia, Anura, Bufonidae). Arq Mus Nac Rio Jan 62: 255-282.

Boquimpani-Freitas L, Rocha CFD AND VAN-SLUYS M. 2002. Ecology of the horned leaf-frog, Proceratophrys appendiculata (Leptodactylidae), in an insular Atlantic rain-forest area of southeastern Brazil. J Herpetol 36: 318-322.

Boquimpani-Freitas L, VRCibradic D, Vicente JJ, BURSEY CR, Rocha CFD AND VAN SLuYs M. 2001. 
Helminths of the horned leaf frog, Proceratophrys appendiculata, from southeastern Brazil. J Helminthol 75: 233-236.

Bursey CR And Goldberg SR. 2007. A new species of Oxyascaris (Nematoda, Cosmocercidae) in the Costa Rica brook frog, Duellmanohyla uranochroa (Anura, Hylidae). Acta Parasitol 52: 58-61.

Bush AO, LAFferty KD, Lotz JM And Shostak AW. 1997. Parasitology meets ecology in its own terms: Margolis et al. revisited. J Parasitol 83: 575-583.

Costa PN, Silva-SoAres T And Bernstein LB. 2009. Defensive behaviour of Proceratophrys boiei (WiedNeuwied, 1824) (Amphibia, Anura, Cycloramphidae). Herpetol Notes 2: 227-229.

DAS I. 1996. Folivory and seasonal changes in diet in Rana hexadactyla (Anura: Ranidae). J Zool 238: 785-794.

DUELLMAN WE. 1999. Distribution patterns of amphibians in South America. In: PATterns of Distributions OF AMPHIBIANS: A GLOBAL PERSPECTIVE. Baltimore. The John Hopkins University Press, p. 255-328.

DUNHAM AE. 1983. Realized niche overlap, resource abundance and intensity of interspecific competition. In: HuEY RD ET AL. (Eds), Lizard Ecology, London: Harvard University, London, p. 261-280.

ETERovick PC AND SAZIMA I. 1998. A new species of Proceratophrys (Anura: Leptodactylidae) from Southeastern Brazil. Copeia: 1998: 159-164.

FÁBIO SP. 1971. Sobre uma nova espécie do gênero Neyraplectana Ballesteros Márquez, 1945 (Nematoda, Cosmocercoidea). Atas Soc Biol Rio de Janeiro 15: 11-13.

FÁBIO SP. 1981. Considerações sobre Cosmocerca parva Travassos, 1925 e C. freitasi Silva, 1954 (Nematoda, Subuluroidea). Rev Bras Biol 41: 25-27.

FREITAS JFT. 1958. Estudos sobre Oxyascarididae (Travassos, 1920) (Nematoda, Subuluroidea). Mem I Oswaldo Cruz 56: 489-559.

Giaretta AA, Araújo MS, Medeiros HF and Facure KG. 1998. Food habits and ontogenetic diet shifts of the litter dwelling frog Proceratophrys boiei (Wied). Rev Bras Zool 15: 385-388.

Giaretta AA, Bernarde OS ANd KoKubum MCN. 2000. A new species of Proceratophrys (Anura: Leptodactylidae) from the Amazon Rain Forest. J Herpetol 34: 173-178.

Gonzalez CE and Hamann Mi. 2004. Primer Registro de Cosmocerca podicipinus Baker y Vaucher, 1984 (Nematoda, Cosmocercidae) en Pseudopaludicola falcipes
(Hensel, 1867) (Amphibia, Leptodactylidae) en Argentina. Facena 20: 65-72.

HAdDAD CFB AND SAzima I. 1992. Anfíbios anuros da Serra do Japi. In: MoRellato LPC (Ed), História Natural da Serra do Japi: ecologia e preservação de uma área florestal no sudeste do Brasil, Campinas, Brasil: Editora da UNICAMP/FAPESP, p. 188-211.

Howard AM, Forester JD, Ruder JM AND POWELL R. 1999. Diets of two syntopic frogs: Eleutherodactylus abboti and E. armstrongi (Leptodactylidae) from the Sierra de Baoruco, Hispaniola. Herpetol Nat Hist 5: 6672.

IzECKSOHN E AND PeIXoto OL. 1981. Nova especie de Proceratoprhys da hiléia bahiana, Brasil (Amphibia, Anura, Leptodactylidae). Rev Bras Biol 41: 19-24.

KWET A And FAIVOVICH J. 2001. Proceratophrys bigibbosa species group (Anura: Leptodactylidae), with description of a new species. Copeia 2001: 203-215.

LiMA AP AND MoreirA G. 1993. Effects of prey size and foraging mode on the ontogenetic change in feeding niche of Colostethus stepheni (Anura: Dendrobatidae). Oecologia 95: 93-102.

Mordeglia C And Digiani MC. 1998. Cosmocerca parva Travassos, 1925 (Nematoda: Cosmocercidae) in toads from Argentina. Mem I Oswaldo Cruz 93: 737738.

Moreira G AND BARreto L. 1996. Alimentação e variação sazonal na freqüência de capturas de anuros em duas localidades do Brasil cantral. Rev Bras Zool 13: 313-320.

Moreira LA, Fenolio DB, Silva HLR and Silva JR NJ. 2009. A preliminary list of the herpetofauna from termite mounds of the cerrado in the Upper Tocantins river valley. Pap Av Zool 49: 183-189.

Prado GM And Pombal JR JP. 2008. Espécies de Proceratophrys Miranda-Ribeiro, 1920 com Apêndices Palpebrais (Anura; Cycloramphidae). Arq Zool 39: 1-85.

Ribeiro MC, Metzer JP, Martensen AC, Ponzoni FJ AND Hirota MM. 2009. The Brazilian Atlantic Forest: How much is left, and how is the remaining forest distributed? Implications for conservation. Biol Conserv 142: 1141-1153.

Rocha CFD, Van Sluys M, Alves MAS, Bergallo HG AND VRCIBRADIC D. 2001. Estimates of forest floor litter frog communities: A comparison of two methods. Austral Ecol 26: 14-21.

Rocha CFD ET AL. 2007. A survey of the leaf-litter frog assembly from an Atlantic forest area (Reserva Ecológica 
de Guapiaçu) in Rio de Janeiro State, Brazil, with an estimate of frog densities. Trop Zool 20: 99-108.

Rodrigues MT. 2003. Herpetofauna da Caatinga. In: LEAL IR ET AL. (Eds), Ecologia e Conservação da Caatinga. Recife, Brasil. UFPE, p. 181-236.

Silva HR, BRITO-PEREIRA MC AND CARAMASCHI U. 1989. Frugivory and seed dispersal by Hyla truncata, a neotropical tree-frog. Copeia 1989: 781-783.

TeIXeIRA RL AND Coutinho ES. 2002. Hábito Alimentar de Proceratophrys boiei (Wied) (Amphibia; Anura; Leptodactylidae) em Santa Teresa, Espírito Santo, sudeste do Brasil. Bol Mus Biol Mello Leitão 14: 13-20.

Travassos L. 1920. Contribuições para o conhecimento da fauna helmintológica brasileira. Arch Escola Sup Agri Med Vet 4: 17-20.
TRAVASSOS L. 1931. Pesquisas helmintologicas realizadas em Hamburgo. IX Ensaio monographico da familia Cosmocercidae Trav., 1925 (Nematoda). Mem I Oswaldo Cruz 25: 237-298.

Vicente JJ, Rodrigues HO, Gomes DC AND Pinto RM. 1990. Nematóides do Brasil, $2^{\mathrm{a}}$ parte: nematóides de anfíbios. Rev Bras Zool 7: 549-626.

Yorke W AND Maplestone PA. 1926. The nematode parasites of vertebrates. London: J and A Churchill, 536 p.

Young BE, Stuart SN, Chanson JS, COX NA AND BOUCHER TM. 2004. Disappearing jewels: the status of New World amphibians. Arlington: NatureServe, $54 \mathrm{p}$.

ZAR JH. 1999. Biostatistical analysis, $4^{\text {th }}$ ed, New Jersey: Prentice Hal, 663 p. 